\title{
A PRESCRIÇÃO INTERCORRENTE EM MATÉRIA TRIBUTÁRIA
}

\author{
Ricardo Pires Calciolari \\ Maximilian Hagl Cordioli \\ Alunos do Curso de Graduação da Faculdade de \\ Direito da Universidade de São Paulo.
}

Resumo:

O escopo do presente artigo é o estudo da prescrição em matéria tributária. Para tanto, uma análise da prescrição no âmbito do Direito Privado foi efetuada. Posteriormente, a prescrição foi cautelosamente examinada no Código Tributário Nacional, levando-se em conta os termos iniciais de sua contagem. Após, as antinomias entre o Código Tributário Nacional e a Lei de Execução Fiscal foram analisadas à luz da norma Constitucional. Ao final, a discussão estendeu-se para um estudo da prescrição intercorrente tanto no processo administrativo quanto no judicial, com análises jurisprudenciais acerca do tema.

\begin{abstract}
:
The main scope of the article is the study of the prescription on tax matter. For that purpose, an analysis of the prescription in private law was done. Futhermore, the prescription was examined more cautiously by the view of National Tax Code. having in mind its initial counting terms. Next, the antinomias between the National Tax Code and the Brazilian Tax Foreclosure Law were analyzed in the light of the Constitutional rule. To accomplish, a study of the prescription on both the administrative and contentious jurisdiction on tax matter was done, bringing court decisions about this theme.
\end{abstract}

Unitermos: prescrição em matéria tributária; início da contagem do prazo; norma geral em matéria tributária: Lei de Execução Fiscal; causas suspensivas e interruptivas da prescrição; prescrição intercorrente.

Keywords: prescription on tax matter; National Tax Code.

1. Diferenciação entre Prescrição e Decadência em Matéria Tributária.

Há muito vem tentando a doutrina privatística estabelecer a correta distinção entre os dois institutos. Ambos têm como fator marcante a influência do elemento tempo somada à inércia do titular do direito subjetivo. No entanto, quanto aos efeitos, a prescrição é susceptivel de ser interrompida, já os prazos de decadência fluem inexoravelmente, não admitindo interrupções ou suspensões. Ademais, a decadência pode ser declarada ex officio pelo juiz, enquanto a prescrição que trata de 
direitos patrimoniais não poderá ser reconhecida e declarada de imediato pelo magistrado, sendo necessária sua alegação pela parte favorecida, conforme preceitua o art. $219, \S 5^{\circ}$ do Código de Processo Civil. ${ }^{\prime}$

Beviláqua define a prescrição como sendu a perda da ação atribuída a um direito e de toda sua capacidade defensiva, em conseqüencia do não uso delas, durante um determinado espaço de tempo. ${ }^{2}$ Durante muito tempo este foi o raciocínio predominante. Contudo, tal premissa levada aos extremos tomaria verdadeira a afirmação de que, decorrido o prazo prescricional, impossibilitado estaria o detentor do direito subjetivo de ajuizar a ação correspondente. Sabemos que tal premissa, à luz dos atuais paradigmas do Direito Processual, foi superada, pois o direito de ação (ou direito de petição, como querem alyuns) é garantido constitucionalmente pelo art. $5^{\circ}$ inciso XXXV O que de fato fica impossibilitado pela prescrição é um julgamento de mérito favorável, caso seja alegado e comprovado o decurso do prazo prescricional pela parte competente. ${ }^{3}$ Ademais, sabemos que após a polêmica de WindscheidMuther consagrou-se entre os processualistas o entendimento de que a ação é um direito autônomo, desvinculado do direito material, subjugando a teoria imanentista. ${ }^{4}$

Nosso atual Código Civil, ${ }^{5}$ no art. 189 , afirma que a prescrição acarreta não a extinção da ação, mas sim de uma pretensão, a qual nasce para o seu titular após ver violado o seu direito. A visão da prescrição como extinção da pretensão e não da ação em si nos parece mais coerente com a doutrina processual, e houve por bem nosso legislador adotá-la.

Assim, a decadência estaria relacionada à não-constituição de determinado direito, ausente qualquer oposição. O sujeito tem a faculdade de

\section{Lei n. 5.869, de 11 de janeiro de 1973.}

2. Bevilàqua, Clóvis. Código Civil dos Estados Unidos do Brasil Comentado. obs. 1 ao artigo 161. Apud Rodrigues, Silvio. Direito Civil. 7. ed. São Paulo: Saraiva, 1977. v. I. p. 312.

3. Como já afirmamos anteriormente, a prescrição, quando se referir a direitos patrimoniais. não pode ser declarada de oficio pelo juiz, conforme preceitua o art. $219, \S 5^{\circ}$ do CPC.

4. Pela escola denominada clássica ou imanentista, a ação seria uma qualidade de todo direito ou o próprio direito reagindo a uma violaçāo. Travada a polêmica entre Windscheid e Muther na Alemanha em meados do século XIX surgiu a ação como direito autônomo, que não pressupõe necessariamente o direito subjetivo material violado ou ameaçado. In: CINTRA, Antônio Carlos de Araújo; GRNOver, Ada Peregrini; Dinamarco, Cândido Rangel. Teoria Geral do Processo. 16. ed. São Paulo: Malheiros, 2000. p. 249-256.

5. Lei n. 10.406 de 10 de janeiro de 2002. em vigor a partir de II de novembro de 2003. 
constituir determinado direito ou de alcançar um status, mas não o fá dentro do período determinado. ${ }^{6}$

A prescrição teria, então, quatro elementos ou condições integrantes:

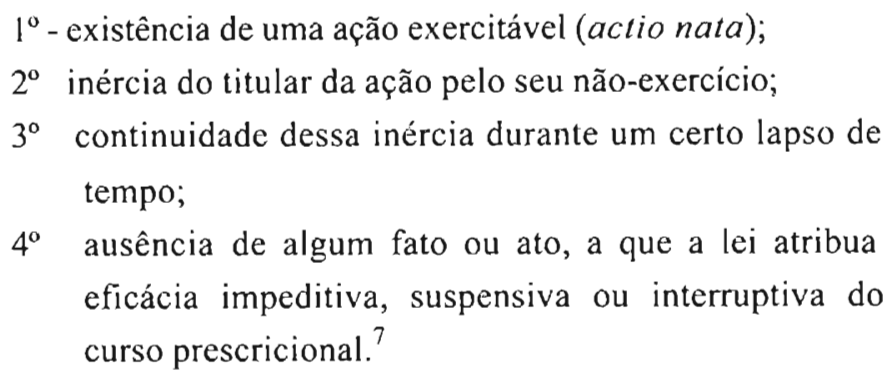

A Constituição disciplina as caracteristicas da prescrição e decadência em matéria tributária de forma especial, afastando o tratamento conferido à matéria pelo Direito Civil. ${ }^{8}$ Resta como simples diferenciação terminológica usar-se decadência para o período até a constituição do crédito e, em seguida, o prazo prescricional para que a fazenda cobre judicialmente o crédito tributário. Desta feita, a decadência estaria relacionada com o direito subjetivo da Fazenda de constituir o crédito tributário e a prescrição com o direito de cobrar (judicial ou extrajudicialmente) o crédito já constituído.

Preceitua o CTN no art. 156, inciso V. que tanto a prescrição quanto a decadência são formas de extinção do crédito tributário. Não-obstante, a decadência se refere à impossibilidade de se constituir o crédito tributário. Também assevera o CTN:

\footnotetext{
6. CAIS, Cleide Previtalli. O Processo Tributário. 3. ed. São Paulo: Revista dos Tribunais. p. $485-$ 490.

7. LeAl, Antonio Luiz da Câmara. Da prescrição e da decadência. Rio de Janeiro: Livraria Acadêmica, 1939. p.19.

8. De fato, conforme veremos posteriormente, preceituou nossa Carta Magna a necessidade de lei complementar para disciplinar a fixação dos prazos prescricionais em matéria tributária. Desta forma, são inaplicáveis os dispositivos acerca da prescrição contidos nos arts. 189 a 206 do Código Civil, pois foram inseridos no ordenamento por meio de lei ordinária. Além disso, o CTN ao tratar de prescrição e decadência o faz de forma especial em relação ao NCC que trata da matéria de forma geral.
} 
Art. 174. A ução para a cobrança do crédito tributúrio prescreve em 5 (cinco anos), contados da data da sua constituição definitiva.

Assim, só há que se falar em prescrição após constituido o crédito tributário, pois antes dele inexiste a própria obrigação tributária.

2. A "constituição definitiva" do crédito tributário e o início da contagem do prazo prescricional.

O momento da constituição definitiva do crédito é essencial no estudo da prescrição em matéria tributária, pois coincide, segundo o art. 174 do CTN, com o início da fluência do prazo de prescricional.

Alguns argumentam que o crédito surgiria com a mera existência do "fato gerador" 9 o que já descartamos, pois não há ainda a formalização do crédito, que se dá com a edição de norma individual e concreta, que é o lançamento tributário.

A ocorrência do evento previsto na lei como "fato gerador" de tributos no plano físico-social é a motivação para que a autoridade administrativa a relate em linguagem competente, fazendo surgir o fato jurídico tributário a partir do qual são determinados tanto os sujeitos ativo e passivo quanto apurado o quantum do tributo, completando a relação tributária. ${ }^{10}$

Assim, o crédito tributário propriamente dito surge quando da formalização da relação tributária, que se dá com o lançamento tributário. Dispõe o art. 142 do CTN:

\section{"Compete privativamente à autoridade administrativa} constituir o crédito tributário pelo lançamento, assim

9. Aqui se deve entender como "fato gerador" o evento ocorrido no mundo dos fatos que se coaduna com o disposto no antecedente da norma tributária (hipótese de incidência), passivel de subsunção através de uma norma individual e concreta editada pela autoridade administrativa competente.

10. Conforme acentua a doutrina de Paulo de Barros Carvalho, a qual assevera que o fato jurídico tributário apenas surgiria após a descrição em linguagem competente do evento previsto como "fato gerador". In: Carvalho, Paulo de Barros. Curso de Direito Tributário. 14. ed. São Paulo: Saraiva, 2002. p. $351-431$. 
entendido o procedimento administrativo tendente a verificar a ocorrência do fato gerador da obrigação correspondente, determinar a matéria tributável, calcular o montante do tributo devido, identificar o sujeito passivo e, sendo caso, propor a aplicação da penalidade cabivel"

Há uma celeuma acerca da natureza declaratória ou constitutiva do lançamento tributário, tema relevante para o estudo da prescrição, pois, como salientado, esta estaria relacionada com o exercício da pretensão do exercício de direito, neste caso, direito de crédito tributário. Como o CTN estabelece ser o lançamento definitivo o termo inicial da fluência do prazo prescricional, e a doutrina ordinariamente entende que a prescrição pressupõe um direito constituído, a melhor opção para uma interpretação sistemática do fenômeno é admitir ter o lançamento natureza constitutiva do crédito tributário.

Sem nos aprofundarmos nesta longa discussão, adotamos a posição do professor Paulo de Barros Carvalho, que entende que "o lançamento tributário é ato jurídico administrativo que põe no ordenamento uma norma individual e concreta: no antecedente, o relato do evento tributário, estabelecendo-o como fato; no conseqüente, a prescrição do vínculo que nasce unindo dois sujeitos em torno de uma prestação pecuniária. Visto na sua integridade, apresenta caráter declaratório do fato e constitutivo da relação" " O crédito, por inerente à relação jurídica, nasce e se extingue com ela.

Outra grande divergência doutrinária fundamental para a disciplina da prescrição envolve a definição de lançamento como ato ou como procedimento. A controvérsia decorre do próprio CTN, que em seu artigo 142, caput o define como procedimento e, logo em seguida, no caput do artigo 150, se refere ao ato de lançamento.

O professor José Souto Maior Borges entende ser o lançamento mais apropriadamente caracterizável como ato e argumenta: "Se o lançamento for caracterizado não-só como ato administrativo, mas também como procedimento, tornar-se-á, teórica e praticamente, penoso, para esse efeito específico, o momento em 
que sc aperfeiçoam e integram os seus elementos estruturais. Partindo-se da contemplação dos diversos atos integrativos do procedimento administrativo, nas diversas fases em que se desdobra, não é fácil optar-se por um deles sem uma certa discrição, para a dımarcação e fixação dos prazos decadenciais e prescricionais" 12

Não nos aprofundaremos nesta discussão, mas para efeito de contagem do prazo prescricional, entendemos imprescindivel na interpretação das normas sobre o lançamento que se possa extrair um momento definido a partir do qual o crédito tributário estará definitivamente constituído. Consideramos. assim. lançado o tributo no ato que encerra o procedimento de lançamento.

Deste modo, antes do advento do lançamento não há obrigação jurídica tributária entre a Fazenda e o contribuinte, mas um poder-dever ${ }^{13}$ da Administração Pública de efetivar o lançamento. ${ }^{14}$

Aperfeiçoa-se o lançamento com o ato de notificação. Notificado o contribuinte, criado está o liame obrigacional tributário, só podendo haver modificação do lançamento, nos termos do art. 145 do CTN caso ocorra: (i) impugnação do sujeito passivo; (ii) recurso de oficio, ou; (iii) iniciativa de oficio da autoridade administrativa (apenas nos casos previstos no artigo 149).

Ora, pela interpretação literal teriamos a paradoxal conclusão de que o crédito tributário definitivo pode ser alterado nos termos do art. 145 do CTN. Contudo, esta modificação do lançamento deve ser entendida como uma constituição

12. Lançamento Trihutário. 2. ed. São Paulo: Malheiros, 1999. p. 100-101.

13. A Administração Pública teria um poder-dever de efetuar o lançamento nos termos da ki geral c abstrata, sob pena de renúncia de receita, conforme preceitua o art. 11 "capuf" da Lei Complementarn. 10I de 4 de maio de 2000:

Art. 11 Constituem requisitos essenciais da respunsabilidade na gestão fiscal a instituição, previsão e efetiva arrucadação de todos os tributos da competência constitucional do ente da Federação.

Ademais, o art. 142 do CTN afirma ser o ato de lançamento um ato vinculado, não tendo a Administração Pública qualquer viés de discricionariedade ao editar a norma individual e concreta do lançamento. De fato, a possibilidade de renúncia de receita se choca com o principio da indisponibilidade do interesse público.

14. Carvalho. Paulo de Barros. Curso de Direito Tributário. 14. ed. São Paulo: Saraiva 2002. p. $351-431$. 
de um novo crédito tributário a partir de novo lançamento e que o crédito anteriormente constituído deixou de existir. ${ }^{15}$

Isto significa que havendo modificação do lançamento em decorrência de qualquer das hipóteses previstas no art. 145 do CTN, esta só será efícaz se dentro do prazo decadencial, salvo se a modificação for motivada por vício formal. Assim, havendo vício formal, a contagem do prazo decadencial se reiniciará na forma do art. 173, inciso II, e seu marco inicial será o início do procedimento de lançamento, segundo parágrafo único do mesmo artigo.

Outra celeuma não-assentada nem pela jurisprudência e tampouco pela doutrina gira acerca do momento de constituição do crédito tributário no lançamento por homologação. De fato, a constituição do próprio lançamento e a conseqüente constituição do crédito tributário se dão em momento anterior à homologação do ato do contribuinte pela Fazenda Pública. Enfim, a lei nesta hipótese dá ao contribuinte competência para constituir o fato jurídico e a obrigação tributária, sendo ele o responsável pelo ato de lançamento. Assim, o ato de homologação não passa de um ato de físcalização, como tantos outros, não sendo ele a verdadeira norma individual e concreta responsável por constituir a obrigação. ${ }^{16}$

Por fim, para a correta abordagem do lema, tomaremos a constituição do crédito tributário conforme singelamente expusemos.

3. Lei Complementar e a Norma Geral em Matéria Tributária.

Antes de passarmos à análise do início da contagem do prazo prescricional devemos, por ora, ingressar neste tema. A justificativa para tanto se encontra no fato de que as regras que disciplinam a contagem dos prazos prescricionais hodiernamente estão disciplinadas tanto no CTN quanto na Lei de Execuções Fiscais, ${ }^{17}$ e muito discute a doutrina acerca das divergências e validades dos dispositivos destes textos normativos.

15. Martins, Ives Gandra da Silva. A prescrição no Direito Tribulário brasileiro. Resenha Tributária, 1975, p. 48.

16. Carvalho, Paulo de Barros. Curso de Direito Tributário. 14. ed. São Paulo: Saraiva 2002. p. 427-43I.

17. Lei n. 6.830 , de 22 de setembro de 1980, doravante LFF. 
Nossa Carta Magna, em seu art. 146, assim dispõe:

Art. 146. Cabe à lei complementur:

1. dispor sobre conflitos de competência, em matéria tributária, entre a União, os Estados, o Distrito Federal e os Municipios;

II. regular as limitações constitucionais do poder de tributar;

III. - estabelecer normas gerais em matéria de legislação tributária, especialmente sobre:

a) definição de tributos e de suas espécies, bem como, em relação uos impostos discriminados nesta Constituição, a dos respectivos fatos geradores, bases de cálculo e contribuintes;

b) obrigação, lunçamento, crédito, prescrição e decadência tributários;

c) adequado tratamento tributário uo ato cooperativo praticudo pelas sociedades cooperativas.

A problemática aqui posta estava presente também no art. $18 \mathrm{da}$ Constituição, de 1969, repetindo o afirmado pela Constituição de 1967 no $\S 1 .^{\circ}$ de seu art. 19, que propugnava serem reservadas à lei complementar as normas gerais de Direito Tributário. A Constituição de 1946 já se referia às normas gerais de Direito Financeiro que. segundo Rubens Gomes de Souza, fora uma forma política encontrada pelo então deputado Aliomar Baleeiro, mas nem mesmo ele poderia indicar ao certo o significado desta expressão ${ }^{18}$

No sentido de esclarecer a celeuma posta, Rubens Gomes de Souza estabeleceu as bases da chamada "Teoria Tricotômica" alertando que "a norma geral

18. Salienta este autor que n deputado Aliomar Baleeiro pretendia atribuir à União competência para legislar de furma ampla sobre Direito Tributário, editando normas com caráter de lei nacional e com os preceitos endereçados ao legislador ordinário dos três poderes tributantes (União, Estados e Municipios), afirma ainda: "(...) perguntado por mim quanto ao sentido que ele the dava (a saber, às normas gerais de direito financeiro). no intuito de ter uma forma de interpretação autêntica, cle me confessou que não tinha nenhuma, que nada mais fora do que um compromisso politico que lhe tinha ocorrido e que tinha dado certo. O importante era introduzir na Constituição a idéia; a maneira de vestir a idéia. a sua roupagem era menos importante do que o seu recebimento no texto constitucional e o pref̧o deste recebimento foi a expressão 'normas gerais', que delimitava, sem dúvida, o àmbito da competência atribuida, mas em termos que nem ele próprio, Aliomar, elaborara ou raciocinara. Era puro compromisso político" In: Comentários ao Código Tributário Nacionul. São Paulo: Revista dos Tribunais, 1975. p. 5. 
não é necessariamente regra de conceituação apenas, mas também regra de atuação." ${ }^{19}$ Assim, a lei complementar teria por escopo: (i) estabelecer normas gerais de Direito Tributário; (ii) dispor sobre conflitos de competência em matéria tributária entre a União, os Estados, o Distrito Federal e os Municípios e; (iii) regular as limitações constitucionais do poder de tributar.

Assim, "as normas gerais de Direito Tributário tinham por função assegurar a atuação uniforme dos preceitos constitucionais referentes a tributos, podendo, para isso, estabelecer o conteúdo das leis tributárias da União, dos Estados e dos Municípios" 20 Como partidários desta tese se encontram Hamilton Dias de Souza $^{21}$ e Bernardo Ribeiro de Moraes. ${ }^{22}$

Acerca das críticas de que a União, deste modo, estaria legislando sobre matéria própria de Estados e Municípios, atentando de forma brutal contra o pacto federativo assevera um dos partidários desta teoria:

"Do ângulo histórico, não é novidade que. contrastando com a origem do federalismo americano, o brasileiro se organizou do centro para a periferia, surgindo de gradativas concessões do poder central e não de fatias soheranas dos estados-membros. A Federação Brasileira, sendo derivada de um estado unitário tradicional desde os tempos coloniais, passando pelo Império, partiu de esquemas e concep̧̧ões fortemente centralizados. Essa situação se refletiu intensamente na área financeira, onde a União, embora fazındo concessões às Federadas e, posteriormente, aos Municípios, sempre se reservou os poderes normativos gerais. O Código de Contabilidade Pública e as leis federais sobre o imposto de vendas e consignações $1 O$

19. Normas gerais de direito financeiro. Revista de Direito Administrativo, v. 37, p. 12-34.

20. Sakakihara, Zuudi. In: Freitas, Vladimir Passos de (Coord.). Execução fiscal: doutrina e jurisprudênciu. São Paulo: Saraiva, 1998, p. 203.

21. Comentário ao Código Tributário Nacional. São Paulo, 1975. 1. I, p. 14.

22. Normas gerais de direito tributário. Revista de Direito Público, n. 31. p. 264. 
Decreto-Lei 915, de 01.12.1938, v.g.) são eloqüentes atestados nesta direção. Dai se infere que, em matéria de normas gerais de Direito Financeiro (e Tributário), a União, primeiro implicitamente e depois de modo expresso, sempre teve competência legislativa. De outra parte, a centralização politica e financeira do Brasil é resultado de fatores econômicos. De um federalismo formal dualista, tendo procurado aproximar-se do modelo americano, que consagra a autonomia periférica de modo inequivoco, cvoluimos (ou involimos?) para um sistema federativo, de que a Carta atual é simbolo, denominado de integração ou cooperativo, no qual a maior parcela do poder tributário está concentrada na esfera da União Federal, com redução considerável da autonomia financeira dos Estados e Municipios".?3

Também Sacha Calmon Navarro Coelho explicita: "o constituinte explicitou pelo fortalecimento das prerrogativas do poder central. Este fato, por si só, explica porque avultou a área legislativa reservada à lei complementar tributária" 24

Consubstanciando outro ponto de vista, Geraldo Ataliba firmara o entendimento de que as "normas gerais de direito tributário não são quaisquer normas de direito tribulário, a dicção do qualificativo 'gerais' já demonstra que se trata de certas e especiais normas e, portanto, implica obrigatoriamente uma limitação, restrição do campo de atuação do legislador complementar" 25 Assim surge a denominada "Teoria Dicotômica"

Assim, partindo do princípio de que as normas gerais de direito tributário não poderiam jamais contrariar os princípios erigidos pela Carta

23. ARZUA, Heron. Contribuição ao estudo dos tributos parafiscais. São Paulo: Rexienha Tributária e IBET. 1974, p. 42. Apud FREITAS, Vladimir Passos de (coord.). Execução fiscal: doutrina e jurisprudencia. São Paulo: Saraiva, 1998. p. 206.

24. Comentários à Constituição de 1988. Rio de Janeiro: Forense. 1990. p. 133.

25. Conteúdo e alcance da competência para editar normas gerais de dircito tributário. Revista de Informaçã Legislativa, p. 75-87. jul./set., 1982. 
Constitucional, dentre eles o princípio federativo. interpreta-se aqui sistematicamente o dispositivo, concluindo-se que a União, mediante lei complementar, pode estabelecer normas gerais de direito tributário para: (i) dispor sobre conflitos de competência tributária entre as pessoas federadas, e; (ii) regular as limitações constitucionais do poder de tributar.

Ataliba complementa: “(...) é afastada de plano a possibilidade das normus gerais tratarem de problemas tais como ordenação de relação juridica tributária, sujeição ativa e passiva, prazos referentes a prescrição e decadência, ato administrativo do lançamento e sua disciplina jurídica, condições para criação da obrigação tributária, forma de extinção do débito, etc." ${ }^{26}$ Deste modo, conclui este doutrinador acerca do CTN que "(...) em seus 217 artigos viola os limites constitucionalmente dispostos às normas gerais, excede a área de competência do Congresso e fere a autonomia dos Estados e Municipios" 27

Souto Maior Borges, também partidário e forte colaborador teórico desta corrente entende que as normas gerais de Direito Tributário "não podem atuar como instrumento de regulação das atividades de uma pessoa pública por outra. Matéria que possa ser disciplinada em leis federais, sstaduais ou municipais, sem perigo de atrito ou usurpação de competência tributária, é insuscetivel de regulamentação por norma de Dircito Tributário" 28

Neste mesmo sentido estão Roque Carrazza e Paulo de Barros Carvalho, que assevera acerca das normas gerais de Direito Tributário: "são aquelas que dispõe sobre conflito de competência entre as entidades tributantes e também as que regulam as limitações constitucionais ao poder de tributar" ${ }^{29}$ e acresce: "Podeo legislador complementar, invocando a disposição do art. 146, III, a, definir um tributo e suas espécies? Sim, desde que seja para dispor sobre conflitos de competência. Ser-lhe-á possivel mexer no fato gerador, na base de cálculo e nos contribuintes de determinado imposto? Novamente sim, no pressuposto de que o faça para dispor sobre conflitos. É quanto à obrigação, lunçamento, crédito, prescrição $e$

26. Normas gerais de direito financeiro e tributário e autonomia dos estados e municipios Revista de Direito Público, n. 10, p. 71.

27. Idem ibidem, p.79.

28. Normas gerais de direito tributário. Revista de Direito Público, n. 31, p. 259.

29. Curso de Direito Tributário. 14. ed.. São Paulo: Saraiva. 2002. p.207. 
decadência tributários? Igualmente, na condição de satisfazer àquela finalidade primordial" 30

Heleno Tôrres, após analisar os três papéis legislativos do Congresso Nacional. ${ }^{31}$ esclarece quais são as matérias sobre sob a égide do princípio da reserva de lei complementar, em duas das funções legislativas do Congresso Nacional:

“I) o exercício de competência da União (lei complementar federal), a qual se subdivide em:

(i) exercicio de competências privativas especificas (arts. 148 e 153, VII, da CF); e

(ii) exercícios de competência residual (arts. 154, I, e 195, $\left.\S 6 .^{\circ} \mathrm{da} C F\right)$,

2) a criação das normas gerais em matéria de legislação tributária (lei complementar nacional arts. 24, I, e 146 da CF), as quais se encontram expressas nas seguintes possibilidades:

(i) regular as limitações constitucionais ao poder de tributar, restritivamente àquelas que exigem leis especificas para surtir efeitos (arts. 146, II, 150, IV. ${ }^{\prime} c \cdot 195, \S 7^{\circ}$ e 156, $\$ 3^{\circ}, d a(F)$;

(ii) evitar eventuais conflitos de competência entre as pessoas tributantes, quando deverá dispor sobre fatos geradores, bases de cálculo e contribuintes dos impostos já identificados na Constituição (arts. 146, I e III, " $a$ " 156, III, e 155, $\$ 2^{\circ}, X I I$, da CF);

(iii) definir os tributos e suas espécies (art. 146, III, ' $a$ ' da $C F)$;

30. Idem ibidem.

31. A saber: "(i) constituinte derivado, ao discutir e votar emendas à Constituição, e é o legislador ordinário da União sob duas modalidades: (ii) legislador federal, ao exercer as competências típicas da União, na qualidade de pessoa de direito público interno plenamente autônoma: e (iii) legislador nacional, ao dispor sobre normas gerais apliciveis às quatro pessoas politicas previstas no art. 24 da Constituição Federal e em outras previstas no corpo da Constituição." In: TÓRRES, Heleno Taveira. Funções das leis complementares no sistema tributário nacional - hierarquia de normas papel do Código Tributário Nacional no ordenamento. Revisıa de Direito Tributário. n. 84. p. 53. 
(iv) harmonizar os procedimentos de cohrança $e$ fiscalização dos tributos, tratando de obrigação, lançamento e crédito (redução de divergências) (arts. 146, III, 'b e 155, $\left.\$ 2^{\circ}, X I I, d a C F\right)$;

(v) uniformizar os prazos de decadência e prescrição (arts. 146, III, 'b da CF), podendo estipular suas exceções; $e$

(vi) fomentar, de modo harmonizado, adequado tratamento tributário ao ato cooperativo praticado pelas sociedades cooperativas" 32

Esta visão, mais adequada aos preceitos da atual Constituição, não encontra paralelo em nenhuma das teorias analisadas anteriormente, pois as competências da norma geral em matéria tributária a ser veiculada por lei complementar não são duas ou três, mas seis, de acordo com os ditames do art. $146 \mathrm{de}$ nossa Carta Magna.

Ademais, não é tal forma de interpretação ofensiva ao federalismo brasileiro por atacar a autonomia dos Estados-membros ou dos Municípios e do Distrito Federal, pois o federalismo adotado no Brasil segue um sistema próprio, esboçado pela nossa própria Constituição. Afasta-se então a teoria dicotômica e a tricotômica. Vale dizer, para o fim de uniformizar os prazos de decadência e prescrição, bem como suas exceções, mister seria a utilização de lei complementar.

\subsection{A validade do CTN frente à Constituição de 1988 .}

O CNT, quando inserido no ordenamento jurídico brasileiro, teve força de Lei Ordinária, redigida sobre a égide da Constituição Federal de 1946, em conformidade com o seu art. $5^{\circ}$, inciso XV, alínea " $b$ " Nosso CNT foi posteriormente recepcionado pela Carta Magna de 1967, que dispunha em seu art. 19, § 1": "Lei Complementar estabelecerá normas gerais de direito tributário, disporá sobre conflitos

32. TÔRRES, Heleno Taveira. Funções das leis complementares no sistema tributário nacional hierarquia de normas -- papel do Código Tributário Nacional no ordenamento. Revista de Direito Tributário, n. 84, p. 54-55. 
de competência nessa matéria entre União, os Estados, o Distrito Federal e os Municipios e regulará as limitações constitucionais ao poder de tributar" Posteriormente foi redigido o Ato Complementar 36, de 13.3.1967, reconhecendo na Lei n. 5.172/1966 as funções exigidas para Lei Complementar, denominando-lhe Código Tributário Nacional.

A Constituição atual dispôs, no art. 34. $\S 5^{\circ}$ dos Atos das Disposições Constitucionais Transitórias que estaria assegurada a aplicação da legislação anterior no que for compativel com a nova Constituição. Assim, pelo principio da recepção constitucional, foi mantido o CTN, sendo plenamente aplicável, posto que tem força de "norma geral tributária" ${ }^{33}$ Atualmente a doutrina tem aceitado a aplicação do CTN, atribuindo-lhe força de lei complementar.

De fato, conforme explicitamos no subitem anterior, as matérias legisladas por este dispositivo legal que tiverem características de norma geral tributária nos termos do art. 146 da Constituição foram recepcionadas pela atual Diploma Maior como lei complementar e só seriam passíveis de alteração por esta espécie normativa. Porém, há de se salientar que os temas do CTN que não versem sobre as matérias específicas reservadas à lei complementar, nas suas seis funções constitucionalmente estabelecidas, foram recepcionados apenas como lei ordinária. podendo ser alterados por meio desta espécie normativa.

\subsection{A validade da Lei de Execuções Fiscais frente ao CTN e à Constituição de 1988.}

A aplicabilidade da LEF no quanto dispõe sobre causas suspensivas e interruptivas da contagem dos prazos prescricionais é muito discutida na doutrina e jurisprudência, visto que parte de seus dispositivos choca-se com a letra do ('TN.

33. "Não há relevância para a discussão sobre ser o Código Tributário Nacional uma lei ordinária, e não complementar. como exigido por esse artigo (a saber, artigo $146 \mathrm{da} \mathrm{CF} / 88$ ), na medida que o artigo 34. $\$ 5^{\circ}$, dos Atos das disposiçōes Constitucionais Transitórias the garantiu força de recepção, alçando-a ao patamar funcional de sobrenorma em matéria de legislação tributária, somente podendo ser revogada, a partir de então, por lei complementar, nos moldes do artigo 146. quando instituida exclusivamente para essa função. É dizer, a partir da Constituição Federal/1988 qualquer dispositivo do Código Tributário Nacional somente poderá ser modificado por lei complementar dirigida especialmente para esse fim, pelo principio da reserva de lei complementar referido no artigo 146" in: TÓRRFS, Heleno Taveira. Funções das leis complemenares no sistema tributário nacional - hierarquia de nomas - papel do código tributário nacional no ordenamentu. Revislu de Direito Tributário, n. 84. 
A LEF foi promulgada em 22 de setembro de 1980, sob a égide da Constituição de 1969, que dispunha no $\S 1^{\circ}$ de seu art. 18\%: "Lei Complementar estabelecerá normas gerais de direito tributário, disporá sobre conflitos de competência nessa matéria entre União, os Estados, o Distrito Federal e os Municípios e regulará as limitações constitucionais ao poder de tributar." 34

Assim, pela aplicabilidade do princípio de reserva legal extraído deste artigo, não haveria necessidade de editar-se lei complementar para editar lei nacional sobre prescrição e decadência, visto que esta matéria não se enquadra no conceito de norma geral de Direito Tributário vinculado por aquela Constituição. ${ }^{35}$ Conclui-se que a LEF, na data de sua promulgação, era plenamente válida e eficaz.

Posteriormente sobreveio a Constituição, de 1988, que aumentou o âmbito das normas gerais tributárias, abarcando também a prescrição e decadência. Contudo, o mesmo dispositivo do Ato das Disposições Constitucionais Transitórias que recepcionou o CTN atuaria da mesma forma com a LEF aplicando-se aqui também o princípio da recepção constitucional.

Assim como ocorreu com o CTN, entendemos que os dispositivos da LEF referentes à matéria reservada à lei complementar pelo art. 146 da Constituição teriam este aspecto normativo, já que foram recepcionados como se de lei complementar fossem. Inexistindo hierarquia e sendo a LEF posterior, conclui-se que esta prevalece sobre o $\mathrm{CTN}$ no tocante à prescrição e à decadência. Contudo esta não é posição unânime.

Muitos negam o caráter de lei complementar da LEF, mesmo dos dispositivos que tratam de matérias reservadas para lei complementar e outros afirmam prevalecer os dispositivos do CTN, por ser este lei ordinária com força de lei complementar. ${ }^{36}$ Assim, a sistemática das disposições do CTN acerca da interrupção e suspensão do prazo prescricional continuariam em vigor, tornando sem efeito os

34. A redação da Constituição de 1967 e da Constituição de 1969 no tocante a esta matéria é idêntica, só se diferem no número do respectivo artigo. Na primeira o disposto encontra-se no $\S 1^{\circ} \mathrm{do}$ arr 19 , na segunda no $\$ 1^{\circ}$ do art. 18.

35. Conforme já analisamos no item 3.3, as funções da norma geral tributária hodiemamente, haja vista nossa Constituição, são seis. Contudo, nas Constituições de 1967 e 1969 elas tinhas função tríplice. sendo, àquela época, perfeitamente aplicável a teoria tricotômica.

36. Sobre hierarquia das leis complementares observar: TôRRES, Heleno Taveira. Furpöes das leis complementares no sistema tributário nacional - hierarquia de normas - papel do cúdigu tributário nacional no ordenamento. Revista de Direito Tributário, n. 84. 
dispositivos da LEF. Contudo, quando esta norma ingressou no ordenamento jurídico (plenamente válida e em vigor), derrogou os dispositivos conflitantes do CTN acerca do tema por ser a norma mais recente, pela aplicação do princípio lex posteriori derrogant priori.

Humberto Theodoro Júnior fundamenta a validade da lei afirmando ser "certo que a prescrição, em si mesma, é mais uma figura de direito material do que processual, a forma de interrompê-la, na pendência do processo, é questão que se comporta perfeitamente entre as regras ou normas do direito processual civil, cujo tratamento legislativo incumbe ao legislador federal ordinário. Não se trata, portanto, de assunto privativo de lei complementar sobre normas gerais de direito tributário" ${ }^{37}$ Neste mesmo sentido argumentam Milton Flaks ${ }^{38}$ e Costa e Silva. ${ }^{39}$

Não lhes assistem razão, pois a C'onstituição determina reserva de lei complementar aos temas prescrição e decadência em matéria tributária e a lei ordinária não poderia, após a Carta de 1988, dispor sobre tal matéria. Contudo, como vimos antes, a LFF tem caráter de lei complementar e seus dispositivos devem ser acatados, por razões distintas daquelas defendidas pelos ilustres processualistas.

Acerca das hipóteses interruptivas e suspensivas do prazo prescricional a favor do Fisco postas na LEF, salientam Humberto Theodoro Júnior e Silva Pacheco screm privilégio odioso, discriminando entre credores a forma de interromper a prescrição, sem razão plausível. ${ }^{40}$

De fato, o privilégio possuido pelo Fisco na execução fiscal se dá em virtude do bem comum, do interesse coletivo, e foi este o princípio que inspirou o

37. Para embasar tal posicionamento invoca o tratadista Humberto Theodoro Júnior a jurisprudência neste sentido: Ap. 57.379. $4^{\mathrm{a}}$ Turma do TRF, ac. 20.08.1980, Rel. Min. Carlos Mario Velloso, DJU, 18.09.1980, p. 7153. Contudo salienta que as atuais posições do STJ e STF têm se inclinado para a harmonização das regras da LEF e do CTN. In: THEODORO JÚNIOR, Humberto. Lei de Execução Fiscal: comentários e jurisprudência. São Paulo: Saraiva, 1995. p. 5I. De fato, a jurispnudência majoritária do nosso Superior Tribunal de Justiça não aceita a aplicabilidade dos dispositivos da LEF conflitantes com o C.TN, conforme veremos.

38. Comentários à Lei de Execução Fiscal. Rio de Janeiro, 1981. p. 194.

39. Teoria e prática do processo executivo fiscal. Rio de Janeiro. p. 242-243.

40. THEODORO JÚNIOR, Humberto. Lei de Excução Fiscal: comentários e jurisprudencia. São Paulo: Saraiva, 1995. p. 50. 
legislador ao editar a $\mathrm{LEF}^{41} \mathrm{O}$ processo executivo fiscal busca, ao fim, resgatar um bem público objeto de crédito tributário. Ora, aqui vemos mais uma atuação do princípio da prevalencia do interesse público sohre o privado, que marca todos os ramos do Direito Público, inclusive o Direito Tributário, daí não ser nem odioso nem injusto os privilégios ao Fisco veiculados pela LEF

4. Início da contagem do prazo prescricional.

A prescrição só existe quando presente a possibilidade de exigir-se a satisfação do direito subjetivo matcrial. No Direito Tributário o crédito estará constituído após a lavratura do lançamento e a respectiva notificação. Porém, entendemos que a exigibilidade surge apenas quando o Fisco puder efetivamente ingressar em juízo com a ação de cobrança.

$\mathrm{O}$ art. 160 do CTN estabelece um período subsidiário de trinta dias para que o contribuinte pague o estabelecido no lançamento sem sofrer os efeitos da mora, caso a legislação tributária não fixar o tempo do pagamento. Nesse sentido, em vista da impossibilidade da Fazenda iniciar uma ação de cobrança neste período, impossível seria se computar o prazo contido neste interregno, ${ }^{42} \mathrm{o}$ início da prescrição, portanto flui somente a partir da mora. ${ }^{43}$

Considerando a correlação entre a exigibilidade e a prescrição, tambím fica impossibilitada a Administração Pública de abastecer seus cofres ocorrendo qualquer das hipóteses elencadas no art. 151 do CTN. Deste modo teríamos que a suspensão da exigibilidade do crédito tributário acarretaria na suspensão dos prazos prescricionais, o que passaremos a analisar adiante.

41. "Este principio, também chamadu de principio da finalidude pública, está presente tanto no momento da elaboração da lei como no momento da sua execução em concreto pela Administração Pública. Ele inspira o legislador e vincula a autoridade administrativa em toda a sua atuação" In: PIrTRu. Maria Sylvia 7anella di. Direito Administrativo. 14. ed. São Paulo: Atlas, 2002. p. 68.

42. PEREjRa, Caio Mário da Silva. Instituições de Direito Civil. Rio de Janeiro: Forense 1961. v. I. p. 476 .

43. Alguns civilistas, ao se dedicarem ao tema da prescrição, afirmaram que as causas que suspendem o início da contagem do prazo prescricional seriam "causas impeditivas", pois não há que se suspender o que ainda não iniciou o seu fluxo. Deste modo, o prazo ficaria impedido de fluir até que cesse a causa devida. Entendemos ser tal discussão meramente terminológica, a qual não influi sobremaneira nas conclusões e assertivas aqui delineadas. Neste sentido observar: PEREIRA, Caio Mário da Silva. Instituições de direito civil. 2. ed. Rio de Janeiro: Forense, 1966. p. 403. 
5. Casos de suspensão da contagem do prazo prescricional no Código Tributário Nacional e na Lei de Execuções Fiscais.

A suspensão se distingue da interrupção, pois esta. conforme Ricardo Lobo Tôrres ${ }^{44}$ recomeça a fluir por inteiro a partir da data do ato que interrompeu ou do último ato praticado no processo (neste sentido está o art. 202, § único, do Código Civil), já a suspensão do prazo prescricional acarreta o reinício de sua contagem, o cômputo do tempo decorrido até o momento da suspensão, que se soma ao que fluir posteriormente.

Embora não tenha tratado sistematicamente o CTN das causas de suspensão da prescrição, elas se fazem presentes. Entendemos aqui que as causas de suspensão da exigibilidade do crédito tributário elencadas no art. 151 do CTN atuam como causas de suspensão dos prazos prescricionais. Isto se dá em virtude do princípio da actio nata, que comanda o instituto da prescrição.

De fato, a prescrição ataca o próprio direito subjetivo material, pois "se o direito é reconhecido, não pode ser desprovido do poder a rem persequendi in iudicio" 45 deste modo "com o perecimento da ação, extingue-se efetivamente o próprio direito" 46 tendo em vista que "a ação é um elemento externo do direito subjetivo, que toma corpo à vista de qualquer lesão" 47 Teriamos de fato a decadência vinculada ao desaparecimento do direito material e a prescrição à impossibilidade do exercício do poder. $^{48}$

Acerca do início de contagem do prazo prescricional, assevera Ovídio Batista da Silva que "no momento em que ocorrer o vencimento, nasce-me uma nova faculdade de que meu direito subjetivo passa a dispor, qual seja poder exigir que meu devedor preste, satisfaça, cumpra a obrigação. Nesse momento, diz-se que o direito subjetivo, que se mantinha em estado de latência, adquire dinamismo, ganhando uma

44. Curso de Dircito Financeiro e Tributário. 8. ed. Rio de Janeiro: Renovar. 2001. p. 270.

45. PEReira. Caio Mário da Silva. Instituições de direito civil. 2. ed. Rio de Janeiro: Forense. 1966. р. 403 .

46. Idem Ibidem.

47. Idem Ibidem.

48. Romano, Santi. Fragmentos de um dicionário juridico. Apud Costa, Alcides Jorge. Decadência, prescrição e prescriçào intercorrente em matéria tributária. Cademas de Direito Tributáio e Finanças Públicas, n. 21 , p. 49. 
nova potência a que se dá o nome de pretensão. A partir do momento em que posso exigir o cumprimento do dever que incumbe ao sujeito passivo da relação jurídica, diz-se que o direito não é efetivamente exigido do obrigado, no sentido de compeli-lo ao pagamento, terei, pelo decurso do tempo e por minha inércia, prescrita essa faculdade de exigir o pagamento" 49

Conforme Antonio Luiz da Câmara Lcal, "sem exigibilidade do direito, quando ameaçado ou violado, ou não-satisfeita a obrigação correlata, não há ação a ser exercitada; e, sem o nascimento desta, pela necessidade de garantia e proteção ao direito, não pode haver prescrição, porque esta tem por condição primária a existência da ação" 50 Neste mesmo sentido salienta o tratadista Washington de Barros Monteiro: "enquanto não nasce a ação não pode elu prescrever. $\dot{E}$ o princípio da actio nata (actio non nata non praescribitur). A prescrição há de concernir a um tempo útil para o exercício da ação. Se o credor não pode agir porque penda condição suspensiva, ainda não verificada, a prescrição não tem curso" 51

Assim, temos que só se pode falar em fluência do prazo prescricional quando nada obste que o titular do direito subjetivo material possa utilizar-se da ação competente para tal fim.

Contudo, esta posição não tem coro uníssono na doutrina. Tributaristas de renomada, dentre os quais Edvaldo Brito, Ives Gandra da Silva Martins. Ruy Barbosa Nogueira e Sebastião de Oliveira Lima discordam desta assertiva.

Como argumento principal suscita-se a inscrição contida no $\S$ único do art. 155 do CTN, que afirma: "o tempo decorrido entre a concessão da moratória e a sua revogação não se computa para efeito da prescrição do direito à cobrança do crédito" Assim, contrariu sensu, querem fazer crer que o CTN restringiu a suspensão da contagem do prazo prescricional apenas a esta hipótese específica de moratória (moratória individual), nos casos de dolo ou simulação de situações para se beneficiarem da moratória.

Neste sentido, Sebastião de Oliveira Lima salienta: "isso nos leva à conclusão de que a moratória, em si, não se constitui em um caso de suspensão de

49. Direito subjetivo, pretensão de direito material e ação. Revista Brasileiru de Direito Processual. v. 37, p. $105-106,1983$.

50. Da prescrição e da deciadência. Rio de Janeiro: Livraria Acadêmica, 1939, p.19.

51. Curso de direito civil. 3. ed. Rio de Janeiro: Saraiva, 1962. v. I. p. 306. 
prescrição. Como esse instituto é um dos casos de suspensão da exigibilidade tributária, temos que esta não implica naquela, vale dizer, a suspensão da exigibilidade do crédito tributário não conduz à suspensão da prescrição" 52

Ives Gandra da Silva Martins entende, na mesma orientação que "o crédito tributário definitivamente constituido e administrativamente suspenso, poderá vir, quando levantada a suspensão, ser juridicamente inexigível se tiver ocorrido a prescrição. (...) o fato de o crédito tributário definitivamente constituido ser inexigivel é absolutamente irrelevante para a ocorrência da prescrição.” E mais, “a prescrição que começa a correr da constituição definitiva do crédito tributário tem vias próprias para ser interrompida e dentre elas nenhuma relacionada com as formas administrativas da suspensão". 53 Assim, no entendimento deste doutrinador, para que a Fazenda assegure seu direito de cobrar judicialmente o crédito, deve utilizar-se dos meios interruptivos da prescrição.

Aliomar Baleeiro, ${ }^{54}$ também adepto deste entendimento, fundamenta sua argumentação no art. 111 do CTN, inciso 1 , que impõe a interpretação literal dos dispositivos do Código Tributário referentes a suspensão e interrupção do crédito tributário. Desta forma, restaria prejudicada a possibilidade de se considerar as hipóteses do art. 151, referentes à suspensão da exigibilidade do crédito como hipóteses de suspensão ou interrupção da prescrição. A única hipótese em que ocorreria a suspensão da prescrição seria a do art. 155, inciso I, pois expressamente prevista no $§$ único do artigo.

Seguindo tal entendimento concluir-se-ia que o Código expressamente admite a manutenção da prescrição mesmo no caso do crédito estar suspenso. O $\S$ único do art. 155 prevê que a revogação da moratória somente é possível antes de prescrito o direito, significando a fluência do prazo prescricional ao mesmo tempo em que o crédito está suspenso pela moratória.

Em sentido contrário afirmam Bernardo Ribeiro de Moraes, (arlos da Rocha Guimarães, Fabio Fanucchi, Francisco de Assis Praxedes, Noé Winkler e

52. Suspensão da prescrição prevista pelo decreto-lei n. 1.569, de 8.8.77, Resenha Tributária, ed. $31,4^{\circ}$ trim., 1977, p. 356.

53. MARTINS, Ives Gandra da Silva. A prescrição no direito trihutário brasileiro. Resenha Tributária, 1975. p. 48ss.

54. Revista de Direito Tributário, n. 9/10, p. 9. 
Sacha Calmon Navarro Coelho não ser este raciocínio o mais exato, pois a interpretação deste dispositivo legal deve ser feita cautelosamente. Quis o legislador dar tratamento especial à moratória individual, na hipótese em que o beneficiário agiu com dolo ou simulação no preenchimento das condições e requisitos, estabelecendo claramente a suspensão da prescrição. Já no que tange à moratória em caráter geral, bem como nos outros casos de suspensão da exigibilidade do crédito tributário, apesar do CTN não dispor expressamente neste sentido, prevalece o princípio geral. ${ }^{55}$

É deste modo que entendemos. Pretendeu o legislador cercar-se da certeza de que situações que envolvam dolo ou simulação das condições para a moratória individual não fossem beneficiadas pela prescrição, por isso consignou esta situação de forma expressa. Nos demais casos em que há a suspensão da exigibilidade do crédito tributário também ficca suspensa a contagem do prazo prescricional. E deste modo mantém-se a interpretação restritiva da norma tributária, pois embora não scja expressa, a suspensão do prazo prescricional se aplicará em virtude de um princípio geral do instituo da prescrição, desta feita mantém-se incólume a interpretação literal dos dispositivos relativos à matéria tributária.

A LEF também elencou causas suspensivas do prazo prescricional:

Artigo $1^{\circ}$ omissis

$\S 3^{\circ} A$ inscrição, que se constitui no ato de controle administrativo da legalidade será feita pelo órgão competente para apurar a liquidez e certeza do crédito $e$ suspenderá a prescrição, para todos os efeitos de direito, por 180 (cento e oitenta) dias ou até a distribuição da execução fiscal, se esta ocorrer antes de findo aquele prazo.

Artigo 40. O juiz suspenderá o curso da execução, enquanto não for localizado o devedor ou encontrados bens sohre os quais possa recair a penhora, e, nesses casos, não correrá o prazo de prescrição.

55. Veloso, Carlos Mário da Silva. A decadência e a prescrição do crédito tributário - as contribuições previdenciária - a lei n. 6.830, de 22.9.1980: disposições inovadoras. Revista de Direilo Trihutário, n. 9-10, p. 80-192. 
Tais dispositivos, como já salientamos, são plenamente válidos e em vigor, visto yue a LEF é norma completar no que tange à esta matéria. Assim, além das hipóteses elencadas nos incisos do art. 151 do CTN, também fica suspensa a prescrição caso ocorram as hipóteses ventiladas pelos arts. $1^{\circ}$, parágrafo $3^{\circ}$ e 40 "caput" da LEF.

Muitos argumentam que fazer valer o art. 40 da LEF acarretaria. além de privilégio odioso, a imprescritibilidade do crédito. De fato, a lei tem por escopo afastar situações em que o devedor dilapida seu patrimônio, aguardando a ocorrência do prazo prescricional para depois constituí-lo novamente. Este tipo de atuação já é notoriamente conhecida, e quis a lei. por oportuno, evitá-la. para o bem do interesse público e resguardo dos bens a que o erário tem direito.

6. Casos de interrupção da prescrição no Código Tributário Nacional e na Lei de Execuções Fiscais.

Afirma o CTN, no § único do artigo 174:

Parágrafo único. A prescrição se interrompe:

I- pela citação pessoal feita ao devedor:

II-pelo protesto judicial;

III - por qualquer ato judicial que constitua em mora o devedor;

IV por qualquer ato inequívoco ainda que extrajudicial, que importe em reconhecimento do déhito pelo devedor.

Contudo, a LEF contém dispositivos que contrariam o disposto no inciso I do citado artigo CTN. De fato, presente aqui a antinomia entre duas normas de igual talante complementar no que diz respeito à matéria prescricional, idênticas quanto à especificidade, deve-se propugnar pela supremacia da mais recente, que é a LEF Tal norma assim dispõe: 
Artigo. $8^{\circ}$ omissis...

$\S 1^{\circ} O$ despacho do juiz que ordenar a citação interrompe a prescrição.

É plenamente válido este dispositivo, sendo que a partir da promulgação da LEF, ficou derrogada a disposição constante no inciso I, parágrafo único do art. 174 do CTN. que dispunha a suspensão da contagem do prazo prescricional somente com a citação pessoal do devedor pelo art. $8^{\circ} \S 1^{\circ}$ da LEF Assim, mero despacho citatório do juiz já basta para suspender o curso do prazo prescricional, irrelevante a citação pessoal do devedor.

Tal dispositivo da LEF, assim como o art. 40 anteriormente mencionado, têm o escopo de evitar situações de inadimplência, já mormente conhecidas e aplicadas por contribuintes de má-fé. a mudança de domicílio. Assim, tal privilégio busca a proteção do erário público contra a má-fé privada, prevalecendo o interesse público face ao interesse privado.

7. Prescrição intercorrente.

7.1. A Pruscrição intercorrente no processo administrativo tributário.

Admitidas pelas razões acima expostas que as causas suspensivas da exigibilidade do crédito tributário são causas suspensivas da prescrição não haverá prescrição intercorrente no processo administrativo, pois. conforme encampa o art. 151 inciso III do CTN, "as reclamações e os recursos, nos termos das leis reguladoras do processo tributário administrativo" são causas suspensivas da exigibilidade do crédito tributário.

Deste modo. através de uma interpretação coerente à lu $<$ legislação tributária atual, a melhor conclusão seria excluir a hipótese da existência de prescrição intercorrente no processo administrativo. Contudo, esta posição não ė uníssona na doutrina. dai muitos afirmarem a ocorrência da prescrição no processo administrativo em virtude da desídia da Administração em promover os atos necessários ao regular andamento do processo. condição necessária para o reconhecimento desta prescrição. 
Neste sentido, Alcides Jorge Costa não se resigna com a demora no julgamento administrativo pela inércia do próprio fisco. ${ }^{56}$ Talvez uma forma de punir o fisco pela sua inércia no julgamento seria a incidência do prazo prescricional durante tal inércia, contudo, como já salientamos anteriormente, isto é impossivel à vista da correta interpretação da legislação em vigor, embora seja condenável a demora desmotivada para o julgamento das causas administrativas.

Eurico Santi ${ }^{57}$ afirma: "Consideramos não haver prescrição intercorrente no processo administrativo porque, quando há impugnação ou recurso administrativo durante o prazo para pagamento do tributo, suspende-se a exigibilidade do crédito, o que simplesmente impede a fixação do início do prazo prescricional"

Vale dizer, admitir a prescrição intercorrente no processo administrativo fiscal é fazer perecer a pretensão do fisco de buscar bens, os quais integrarão erário público. A tentativa de impor a contagem do prazo nesta situação não se coaduna com a interpretação exposta e, por mais, fará o Estado, na persecução do bem público, sofrer a ocorrência de prescrição sem que possa, por outro lado, adotar medidas para assegurar a cobrança dos tributos, já que a exigibilidade do crédito tributário estará suspensa durante o julgamento dos recursos administrativos.

\subsection{A prescrição intercorrente na execução fiscal.}

O mesmo raciocínio aplica-se para a prescrição intercorrente no âmbito da execução fiscal. Não-obstante, devemos salientar que aqui também está envolvida a aplicação da LEF. a qual abarca hipóteses de suspensão e interrupção dos prazos prescricionais muito mais benéficas ao físco do que o disposto no CTN, questão que já discutimos anteriormente.

Aqui também há os que argumentam, como na prescrição intercorrente no processo administrativo, a possibilidade da ocorrência do prazo prescricional em

56. CosTA, Alcides Jorge. Decadència, prescrição e prescrição intercorrente em matéria tributária. Cadernos de Direito Tributário e Finanças Públicas, n. 21, ano 5, outubro/dezembro de 1997.

57. Apud PIMENTA, Marcos Rogério Lyrio. A prescrição intercorrente no processo administrativo tributário. Revista Dialética de Direito Tributário, n. 71, p. 120. 
havendo desleixo, negligência ou inércia da Administração para a consecução dos atos processuais que se fazem necessários para o correto deslinde do processo. ${ }^{58}$

Há nesta doutrina nítida confusão. A desídia no processo pode acarretar, conforme preceitua o art. 267 inciso V e 268, parágrafo único, do CPC, a extinção do processo ou, quiçá, impedir a repropositura da ação, caso o autor (in casu a Fazenda Pública) der causa, por três vezes, à extinção do processo sem julgamento do mérito por desídia, que se denomina perempção. ${ }^{59}$ Ora, as hipóleses contidas na LEF como suspensão ou interrupção do prazo prescricional não se dão por desídia do Fisco, são situações expressamente previstas em lei. A inércia do fisco pode sim, acarretar a perempção, não a ocorrência do prazo prescricional.

Outrossim, não se poderia, como querem alguns, descartar a incidência da $\mathrm{LEF}^{60}$ pois esta foi recepcionada com força de Lei Complementar. Outros pretendem que se admita, na hipótese de arquivamento do processo nos termos do $\S$ $1^{\circ}$ do art. 40 da LEF. não a suspensão do prazo, mas uma interrupção. Neste sentido podemos encontrar Humberto Theodoro Júnior, ${ }^{61}$ Milton Flaks ${ }^{62}$ e Costa c Silva. ${ }^{63}$

Ora, o próprio caput do art. 40 da LEF dcixa claro que, naquelas situações, "não ocorrerá o prazo de prescrição" O arquivamento dos autos, nos termos do $\S 1^{\circ}$ do art. 40 da LEF. não-acarreta inicio de nova contagem, pois a lei nada dispõe a este respeito. Observou o legislador a atual situação dos juízos, varas e tribunais, com excesso de autos, decidindo por bem que processos paralisados (não pela inércia da Fazenda Pública, frise-se, mas pela não-localização do devedor ou de bens a serem penhorados) a mais de ano deverão ser arquivados. evitando o acúmulo demasiado e desnecessário de processos nas varas judiciárias que sabemos já ser de grande monta. Tal a veracidade destes argumentos que não se olvidou o legislador a

58. Neste sentido, observar PIMLNTA, Marcos Rogério Lyrio. A prescriçào intercorrente no processo administrativo tributário. Revista Dialética de Direito Tributärio. n. 71, p. 120 e BITTAR. Djalma. Prescrição intercorrente em processo administrativo de consolidação do crédito tributário. Revista Dialética de Direito Tributário, n. 72.

59. Sobre o tema, afirma a Súmula do STJ n. 240 que "a extinção do processo, por abandono de causa pelo autor, depende de requerimento do réu"

60. Observar o já salientado no item 3.

61. Lei de Execução Fiscal: comentários e jurisprudência. São Paulo: Saraiva, 1995. p. 51.

62. Comentários à Lei de Execução Fiscal. Rio de Janeiro, 1981. p. 194.

63. Teoria e práticu do processo executivo fiscal. Rio de Janeiro. p. 242-243. 
determinar, já no $\S 2^{\circ}$. o desarquivamento dos autos caso encontrado o devedor ou bens penhoráveis, sem, contudo, marcar algum prazo para tal desarquivamento.

Assim, esta hipótese é claramente de suspensão da contagem do prazo prescricional. Vale dizer, impossivel se cogitar de interrupção do prazo prescricional após arquivados os autos, pois a lei nada dispôs neste sentido. Ademais, seria ilógica a ocorrência do prazo prescricional, quando desaparecido o devedor ou os bens, favorecer-se-ia o devedor (mormente aquele que, de forma criminosa, omite seu paradeiro para evitar a perseguição dos credores) em face do Fisco, que aqui persegue bem público integrante do erário.

\section{A Interpretação Jurisprudencial.}

8.1. A Jurisprudência das Cortes Administrativas.

Por muitas vezes se manifestou o Conselho de Contribuintes acerca da suspensão da contagem do prazo prescricional em virtude de impugnação ou recurso administrativo. Deste modo, a grande maioria das decisões foram no sentido de que, conforme expusemos anteriormente no item 5 , a propositura de impugnação na esfera administrativa, por ser causa suspensiva da exigibilidade do crédito tributário nos termos do art. 151, inciso III do CTN, é causa suspensiva da contagem do prazo prescricional. Como exemplo podemos mencionar:

Conselho de Contribuintes - Recurso n. 127317 Terceira Câmara - Relatora Conselheira Mary Elbe Gomes Queiroz.

Prescrição Intercorrente na via Administrativa Em prestigio ao devido processo legal, ao contraditório e à ampla defesa, bem assim à isonomia na relação juridicotributária não é admissivel a prescrição intercorrente no Processo Administrativo Tributário. A apreciação da lide tributária em via administrativa é imprescindivel, como forma de ser exercido o controle da legalidade, tendo em vista que somente poderá ser exigido crédito tributário quando efetivamente comprovada a ocorrência do fato 
gerador e do respectivo quantum. Haja vista a suspensão da exigibilidade do crédito tributário como prevista no CTN, não há qualquer prejuizo a ser invocudo. ${ }^{64}$

Vê-se que tal jurisprudência coaduna-se com o anteriormente exposto. Ademais, vale salientar que expôs a relatora a necessidade de se ver o crédito tributário corretamente apurado durante o processo administrativo, vale dizer, além da Fazenda estar impedida de cobrar o crédito tributário, enquanto penda condição suspensiva, tal cobrança seria impossível, posto que os valores ainda estão pendentes de correta apuração no curso deste processo.

Contudo, é possível encontrar jurisprudência em sentido diverso, argumentando que haja, pela interposição de recurso administrativo, causa interruptiva do prazo prescricional, como o que segue:

Conselho de Contribuintes - Recurso n. 129951 Quinta Câmara-Relator Conselheiro Daniel Sahagoff. Processo Administrativo Prescrição Intercorrente Lavrado o auto de infração e apresentada impugnação ao

64. É nesse sentido a jurisprudência majoritária do Conselho de Contribuintes, a qual pode ser verificada através da observação dos seguintes acórdãos (por n. de processos): $11080.001751 / 95-15$, $10805.000206 / 93-28,10880.000670 / 2001-19,10650.001118 / 95-34,10680.001252 / 97-86$, $10880.036|62 / 9|-46, \quad 10880.036165 / 91-34, \quad 13609.000285 / 95-61, \quad 13805.001839 / 92-51$, $13805.001841 / 92-01, \quad 10783.001683 / 94-60,10830.006780 / 94-63,13884.000989 / 2002-75$, $10167.002794 / 90-27, \quad 10120.001501 / 92-10, \quad 10665.000636 / 95-53, \quad 13410.000118 / 96-46$, $10880.020613 / 90-33, \quad 10680.009905 / 94-69, \quad 10768.003284 / 90-34, \quad 10768.003283 / 90-71$, $10768.003282 / 90-17, \quad 10768.003285 / 90-05, \quad 10880.044748 / 88-42, \quad 10880.044748 / 88-42$, $10880.044748 / 88-42, \quad 13805.001954 / 92-90, \quad 13805.001955 / 92-52, \quad 13805.001958 / 92-41$, $13805.001957 / 92-88, \quad 10880.029901 / 88-01, \quad 10665.000643 / 95-19, \quad 13706.000220 / 90-77$, $10768.003286 / 90-60, \quad 10768.003287 / 90-22, \quad 10880.044750 / 88-94, \quad 10768.003289 / 90-58$. $10768.003288 / 90-95, \quad 10880.038953 / 91-92, \quad 10768.022449 / 91-21 . \quad 10768.022450 / 91-18$, $11020.000737 / 96-35,10880.002599 / 2002-81,10860.000346 / 97-74,10855.001552 / 96-62$, $13708.000102 / 95-71, \quad 10805.002736 / 94-73, \quad 10880.019960 / 95-64.10845 .006052 / 94-56$, $13805.001843 / 92-29, \quad 13805.001842 / 92-66, \quad 11070.000031 / 92-17, \quad 10880.036915 / 92-11$, $10805.003147 / 94-58, \quad 10880.036911 / 92-52, \quad 10880.036913 / 92-88, \quad 10880.036912 / 92-15$, $10880.036914 / 92-41, \quad 10880.044752 / 88-10, \quad 10783.001756 / 94-31 . \quad 11030.002713 / 95-66$, $10120.001248 / 90-88, \quad 13802.001081 / 91-46, \quad 10508.000278 / 91-21, \quad 10830.001682 / 88-19$, $10882.001304 / 94-31, \quad 10768.013269 / 92-39, \quad 10665.000644 / 95-81$. 10880.066683/93-90, 10830.006617/89-15, 13971.000243/92-77, 10880.033978/89-I ]. Intre muitos outros, proferidos por várias câmaras em diferentes composições. 
mesmo, instaura-se a lide administrativa, interrompendose a contagem de prazos decadencial ou prescricional. ${ }^{65}$

Não há qualquer razão para se cogitar em interrupção, pois, como já expusemos, as condições suspensivas da exigibilidade do crédito tributária também suspendem o cômputo do prazo prescricional.

Também há jurisprudências que aceitam o curso do prazo prescrição durante o curso do processo administrativo por outros motivos, vejamos:

Conselho de Contribuintes - Recurso n. 97674 Segunda Câmara -- Relator Conselheiro Oswaldo Tancredo de Oliveira.

Processo Administrativo Fiscal -.. Prescrição Intercorrente - Inadmissivel em face da inocorrência comprovada de omissão das autoridades preparadoras, conforme reiterada jurisprudencia deste $e$ dos demais Conselhos. MÉRITO. Comprovados os fatos constantes da denúncia. Nega-se provimento ao recurso.

Neste acórdão, apesar de negar-se a ocorrência da prescrição intercorrente no caso concreto, admite-se a possibilidade de que esta venha a existir, quando presente e comprovada a omissão das autoridades preparadoras. Como vimos, não há previsão legal neste sentido, permanecendo válida então a regra geral de que só pode haver prescrição, quando for possível tomar-se medidas judiciais de cobrança do crédito (princípio da actio nata).

No Tribunal Paulista de Impostos e Taxas há a Súmula de n. 04/2003 que dispõe: "não é admissivel prescrição intercorrente no processo administrativo tributário" Isto mostra que o entendimento majoritário em âmbito administrativo

65. Neste mesmo sentido: 10880.020987/90-11, 10880.020986/90-41, 10880.020984/90-15, 10880.020988/90-76. Todos da $5^{\mathrm{a}}$ Câmara proferidos na sessão de 28.01.2003. 
tende hoje a admitir o quanto aqui fora exposto, não obstante possa-se verificar a existência de acórdãos em sentido contrário. ${ }^{66}$

8.2. A Jurisprudência das Cortes Jurisdicionais.

Quanto ao tema. nossa jurisprudência apresenta inúmeros paradoxos. Há uma grande predominância de julgados afastando a incidência da LEF e seus dispositivos, afirmando que o disposto nesta lei, dita ordinária pela jurisprudência majoritária, deve se pacificar com o já disposto pelo CTN, que teria força de lei complementar e, portanto, seria hierarquicamente superior.

Para ilustrar este posicionamento, hodiernamente dominante:

Superior Tribunal de Justiça - Agravo em Recursos Especial n. 439560, Roraima, Relator Ministro Paulo Medina, Diário da Justiça de 14.04.2003.

Agravo em Recurso Especial - Processual Civil e Tributário - Execução Fiscal - Suspensão - Prescrição Intercorrente.

A aplicação do art. 40 da Lei n. 6.830/80 (LEF) se sujeita aos limites impostos pelo art. 174 do CTN. Assim, após o transcurso do prazo qüinqüenal sem a manifestação da Fazenda Pública. impõe-se a decretação da prescrição intercorrente. Precedentes. Agravo regimental a que se nega provimento.

66. Nos acórdãos proferidos no curso dos processos de n. DRT. 1 - 1424/87. da 4 " Câmara e de n. DRT. 1 - 3792/89 admitem a prescrição como forma de punição pela desídia da Fazenda em dar correto andamento ao processo administrativo tributário. Neste último acórdão mencionado pode-se verificar a grande controvérsia que ainda reside entre os julgadores. 
Este é, infelizmente, o panorama majoritário da nossa jurisprudência. ${ }^{67}$ Deste modo, a tese prescrição intercorrente durante o processo judicial tende a ganhar força, já que seu respaldo jurisdicional é sempre freqüente. É dizer, a tese de que a LEF deve ser interpretada restritivamente, de forma a se sujeitar aos limites impostos pelo CTN foi adota por grande parte da nossa jurisprudência.

Vejamos o paradoxo. Num primeiro momento esta jurisprudência tende a afirmar uma necessidade de que os conceitos preconizados pela LEF devem se amoldar ao que fora disposto pelo CTN, que é lei complementar, e assim sendo, hierarquicamente superior. Ora, como vimos, não há hierarquia entre normas ordinárias e complementares, existe, na realidade, matéria reservada somente ao legislador complementar, não podendo o legislador ordinário dispor sobre determinado tema abarcado pela reserva.

Outrossim, dizer que LEF não tem caráter complementar é mais um paradoxo, pois o mesmo dispositivo constitucional que recepciona o CTN e lhe dá caráter de norma geral em matéria tributária e, portanto, de lei complementar, recepcionou também a LEF Dizer que qualquer das normas não tem caráter complementar no que tange à disciplina de competência de norma geral tributária (nos termos do art. 146, inciso III da Constituição Federal), é dizer que a outra norma também não o tem, vale dizer, ou ambas foram recepcionadas pelo constituinte de 1988 com caráter de normas gerais em matéria tributária ou ambas não o foram.

Também nossos tribunais têm, com certa freqüência, admitido o instituto da prescrição intercorrente como medida punitiva ao Fisco, como forma de garantir a segurança jurídica ou por vezes para assegurar a imprescritibilidade de divida. Segue exemplo do exposto:

Tribunal de Justiça do Rio de Janeiro - Embargos Infringentes na Apelação Cível n. 16.246 - Duque de

\footnotetext{
67. Para tal observação, basta verificar os seguintes acórdãos do STJ (por n. de processos): 200300199956 - MA, 200300446360 - RO, 200300991635 - RO, 199800697292 - SP, 200200522492 - RO, 200200258672 - RO, 200200338827 - RO, 199800474153 - SP, 200101220932 - PR, 200100740185 - PE, 199800444726 - SP, 200000242764 -SP, 199800824847 - SC, 199700177858 SP, 200000165654 - DF, 199900501420 - SP, 199100028037 - RJ. Também do TRF da $5^{3}$ Região: 9905616713 - AL. TRF da 1" Região: 200201000158778 - BA, 200201000094940 - BA, 200101000496127 - BA. Do TRF da 23 Região: 200102010169076 - RJ. Também do extinto Tribural Federal de Recursos, Apelação Cível n. 94.370 - SP. Entre muitos outros, proleridos por várias turmas e câmaras em diferentes composiçōes.
} 
Cuxias $-2^{\circ}$ Grupo de Câmaras - Relator Desembargador Orlindo Elias, in: Revista de Direito Público, n. 65, janeiro/março de 1983.

$$
\text { Imposto - Lançamento - Recurso -. Exigibilidade }
$$

Suspensa - Prazo Prescricional Intercorrente Preliminar acolhida.

O lançamento do crédito tributário importa a sua constituição definitiva. O recurso administrativo suspende a sua exigibilidade, interrompendo, por isso, a prescrição. Se porém, o uparelho fiscal não decide recurso a tempo, deixando transcorrer tempo superior ao do prazo prescricional, ocorre a prescrição intercurrente. ${ }^{68}$

Aqui vemos um claro exemplo de prescrição utilizada com caráter punitivo. De fato, a desídia do Fisco para dar andamento ao processo administrativo no mais das vezes é injustificável, verdadeiro atentado ao direito de defesa e a segurança jurídica. Contudo, não se pode entender que, suspensa a exigibilidade do crédito tributário, volte a correr o prazo prescricional, pelos motivos supramencionados. Este caráter punitivo que tem a prescrição só pode ser aplicado, quando o detentor do direito encontra em mãos meios de cobrança e não os utiliza, quedando-se inerte (princípio da actio nata). Não é este o caso, aqui o credor se encontra impedido de cobrar o crédito, sendo incabível falar-se em prescrição, mesmo que o prolongado prazo de duração da causa de inexigibilidade do crédito ocorra por pura desídia da Fazenda Pública. Deve-se sim, criar mecanismos que garantam maior celeridade ao julgamento administrativo (maior aparelhamento da máquina estatal, contratação de pessoal, modernização tecnológica, entre outras formas) e não-fazer incidir a prescrição em casos que sabidamente a lei não a faz incidir.

Contudo, há ainda julgados que optaram pelo raciocínio inverso. $O$ extinto Tribunal Federal de Recursos, na Súmula de n. 153, afirmava: "constituído, no qüinqüênio, através de auto de infração ou notificação de lançamento, o crédito tributário, não há falar em decadência, fluindo, a partir dai, em princípio, o prazo 
prescricional, que, todavia, fica em suspenso, até que sejam decididos os recursos administrativos". Não-obstante, tal Súmula apresentou discrepâncias na sua aplicação:

Tribunal Federal de Recurso - Apelação n. 85427 PB, Diário da Justiça de 13.12.84.

"Se o procedimento administrativo fiscal ficou paralisado durante oito anos, por culpa exclusiva dos Agentes Fazendários, é de ser proclamada a prescrição intercorrente. Em tal caso não tem aplicação a Súmula 153 desta Corte, que se refere a prescrição comum e não é prescrição intercorrente." ${ }^{69}$

Neste outro está presente a adoção da prescrição intercorrente com caráter punitivo para a desídia processual:

Superior Tribunal de Justiça - Recurso Especial n. 237.079, Relatora Ministra Nancy Andrighi, Diário da Justiça de 11.09.2000.

Tributário e Processo Civil Execução Fiscal ICMS - Impulsão Processual - Inércia da parte credora Estagnação por mais de 5 anos - Prescrição Intercorrente - Reconhecimento - Artigo 40 da Lei $n$. 6.830/80 e Artigo 174 do CTN. Precedentes do STJ e STF

I- A regra inserta no artigu 40 da Lei n. 6.830/90, por ser lei ordinária, deve harmonizar-se com o artigo 174 do CTN, de modo a não tornar imprescritivel a divida fiscal e eternizar as situações juridicas subjetivas.

II Em sede de execução fiscal a inércia da parte credora em promover os atos de impulsão processual, por mais de cinco anos, pode ser causa suficiente para deflagrar a prescrição intercorrente, se a parte

69. No mesmo sentido, também do Tribunal Federal de Recursos, a Apelação n. 34.684 - RS, e do STF o Recurso Extraordinário n. 80.685 - PR. 
interessada, negligentemente, deixa de proceder aos atos de impulso processual que lhe compete.

III-Recurso Especial a que se nega provimento.

Como vimos, a desídia da Administração Pública em promover os atos de impulsão processual pode dar ensejo à extinção do processo sem julgamento do mérito, nos termos do art. 267, inciso III do CPC, mas não à prescrição intercorrente. É mais um paradoxo apresentado pela nossa jurisprudência acerca do tema.

Há ainda julgados em sentido contrário, alguns rechaçando a existência de prescrição intercorrente durante o processo administrativo fiscal, por se encontrar pendente ainda condição suspensiva, outros excluindo a ocorrência da prescrição intercorrente no curso do processo judicial, através da correta interpretação da LEF:

Superior Tribunal de Justiça - Recurso Especial n. 435986, Relatora Ministra Eliana Calmon. Diário da Justiça de 20.10.2003.

Tributário Decadência e Prescrição.

1. A antiga forma de contagem do prazo prescricional, expressa na Súmula 153 do extinto TFR, tem sido hoje ampliada pelo STJ, que adotou a posição do STF

2. Atualmente, enquanto há pendência de recurso administrativo, não se fala em suspensão do crédito tributário, mas sim em um hiato que vai do inicio do lançamento, quando desaparece o prazo decadencial, até o julgamento do recurso administrativo ou a revisão exofficio.

3. Somente a partir da data em que o contribuinte é notificado do resultado do recurso ou da sua revisão, tem inicio a contagem do prazo prescricional.

4. Prescrição intercorrente não ocorrida. porque efetuada a citação antes de cinco anos da data da propositura da execução fiscal.

5. Recurso especial improvido. 
Superior Tribunal de Justiça - Recurso Especial $n$. 293946, Relator Ministro Francisco Peçanha Martins, Diário da Justiça de 26.05.2003.

Execução Fiscal - Devedor não Localizado Suspensão do Processo-Possibilidade Lei n. 6.830/80, art. 40.

- Não sendo localizado o devedur, o processo executivo será simplesmente suspenso, mas não-extinto.

- Transcorrido um ano da suspensão do processo será ele arquivado e, a qualquer tempo, poderá ser reativado se encontrados o devedor ou bens penhoráveis.

- Recurso conhecido e provido. ${ }^{70}$

Tribunal Regional Federal da $5^{a}$ Região Apelação Civel n. 177227, Relator Desembargador Federal Edilson Nobre, Diário da Justiça de 17.06.2003.

Processual Civil - Execução Fiscal - Extinção sem Julgamento do Mérito - Abando - Art. 267, III, $\S I^{\circ}$, do CPC - Hipótese de Suspensão - Art. 40, da Lei n. 6.830/80 (LEF).

1. ('itado o devedor, não foram, contudo, encontrados bens em nome do executado, do que decorreu não ter sido realizada a penhora. A hipótese fática enconcreto subsume-se ao comando do art. 40 da Lei n. 6.830/80 (LEF), e não ao da norma contida no art. 265, III, § $1^{\circ}$ do ('PC. Tratando-se de norma especial, a LEF afasta a incidência da norma processual geral.

2. Não encontrados bens para efetivação du penhora, o juiz deve determinar a suspensão do processo, intimando o exeqüente para tomar as providências devidas. A ausència de fornecimento dos elementos necessários ao prosseguimento da execução, no decorrer 
du suspensão, implicará, ao final de um ano, no arquivamento sem baixa dos autos, e não nu extinção do feito sem julgamento do mérito.

3. Pelo provimento da apelação.

Aqui vemos que optaram os julgadores em adotar os dispositivos da LEF e em afastar a possibilidade da utilização da prescrição como punição para a desidia tanto no processo administrativo quanto no processo judicial.

8.3. Conclusões acerca da análise Jurisprudencial.

Do quanto fora exposto nesta análise jurisprudencial pode-se verificar uma forte tendência das cortes administrativas em rechaçar a incidência da prescrição intercorrente, enquanto pendente de julgamento recurso administrativo. Quanto à jurisprudência das cortes jurisdicionais vê-se uma tendência em também não-admitir a prescrição intercorrente no processo administrativo, enquanto penda condição suspensiva da exigibilidade do crédito tributário, contudo existem julgados recentes e em sentido contrário.

Já no que diz respeito à jurisprudência acerca da prescrição intercorrente no curso do processo judicial, vê-se uma forte tendência em admiti-la. afastando-se a incidência da LEF e utilizando o CTN. Não-obstante, há julgados defendendo ambas as posições, o que só vem a demonstrar que a problemática acerca deste tema, além de doutrinária, é também jurisprudencial.

10. Conclusões.

Diante de tudo quanto fora exposto podemos chegar às seguintes conclusões acerca da prescrição em matéria tributária:

1) O marco inicial da contagem do prazo se dá após constituído o crédito tributário, com o lançamento regularmente notificado (conforme art. 142 do CTN), depois de vencida a divida (aplicando-se 
subsidiariamente o art. 160 do CTN), podendo ser este marco postergado, enquanto encontrar-se pendente quaisquer das causas suspensivas da exigibilidade do crédito tributário (art. 151 do C.TN).

2) As causas suspensivas da contagem do prazo prescricional são as causas suspensivas da exigibilidade do crédito tributário contidas nos incisos do art. 151 do CTN, bem como as hipóteses do $\S 3^{\circ}$ do art. $2^{\circ}$ e do caput do art. 40 , ambos da LEF, quais sejam:

(i) moratória (art. 151, inciso I do CTN );

(ii) o depósito do seu montante integral (art. 151, inciso II do CTN);

(iii) as reclamações e os recursos, nos termos das leis reguladoras do processo tributário administrativo (art. 151, inciso III do CTN);

(iv) a concessão de medida liminar em mandado de segurança (art. 151, inciso IV do CTN);

(v) a concessão de medida liminar ou de tutela antecipada, em outras espécies de ação judicial (art. 151 , inciso $\mathrm{V}$ do $\mathrm{CTN}$ );

(vi) o parcelamento (art. 151, inciso Vl do CTN);

(vii) a inscrição do crédito tributário em divida ativa, suspendendo a prescrição por 180 dias ou até a distribuição da execução fiscal (art. $2^{\circ}, \S 3^{\circ}$ da LEF);

(viii) a não-localização do devedor (art. 40 caput da LEF);

(ix) a não-localização de bens penhoráveis (art. 40 caput da LEF).

3) As causas interruptivas do prazo prescricional são as dispostas nos incisos II, III e IV do parágrafo único 
do art. 174 do CTN, bem como a hipótese do $\S 2^{\circ}$ do art. $8^{\circ}$ da LEF, quais sejam:

(i) protesto judicial (art. 174, parágrafo único, inciso II do CTN);

(ii) qualquer ato judicial que constitua em mora o devedor (art. 174, parágrafo único, inciso III do CTN);

(iii) qualquer ato inequívoco ainda que extrajudicial, que importe em reconhecimento do débito pelo devedor (art. 174, parágrafo único, inciso IV do CTN);

(iv) o despacho do juiz que ordena a citação (art. $8^{\circ}, \S 2^{\circ}$ da LEF).

4) Fica prejudicado o reconhecimento da prescrição intercorrente, tanto no processo judicial quanto no processo administrativo.

São Paulo, setembro de 2004.

10. Bibliografia.

AMARO, Luciano. Direito tributário brasileiro. 5. ed. São Paulo: Saraiva, 2000.

ARZUA, Heron. Contribuição ao estudo dos tributos parafiscais. São Paulo: Resenha Tributária e IBET, 1974. p. 42.

ATALIBA, Geraldo. Conteúdo e alcance da competência para editar normas gerais de direito tributário. Revista de Informação Legislativa, jul./set., 1982, p. 75-87.

ATALIBA, Geraldo. Normas gerais de direito financeiro e tributário e autonomia dos estados e municípios. Revista de Direito Público, n. 10.

BALEEIRO, Aliomar. Revista de Direito Tributário, n. 9/10. p. 9.

BATISTA, Ovidio. Direito subjetivo, pretensão de direito material e ação. Revista Brasileira de Direito Processual, v. 37, 1983, p. 105-106.

BITTAR, Djalma. Prescrição intercorrente em processo administrativo de consolidação do crédito tributário. Revista Dialética de Direito Tributário, n. 72.

BORGES, José Souto Maior. Normas gerais de direito tributário. Revista de Direito Público, n. 31, p. 259. 
CAIS, Cleide Previtalli. O processo tributário. 3. ed. São Paulo: Revista dos Tribunais, 2001.

CARVALhO, Paulo de Barros. Curso de direito tributário. 14. ed. São Paulo: Saraiva, 2002.

CINTRA, Antônio Carlos de Araújo; GRINOVER, Ada Peregrini; DINAMARCO, Cândido Rangel. Teoria Geral do Processo. 16. ed. São Paulo: Malheiros, 2000.

COELHO, Sacha Calmon Navarro. Decadência e prescrição contra a fazenda pública - termos iniciais e finais -- regras de contagem. Resenha Tributária, ano VII, 1976.

COELHO, Sacha Calmon Navarro. Comentários à Constituição de 1988. Rio de Janeiro: Forense, 1990.

COSTA, Alcides Jorge. Decadência, prescrição e prescrição intercorrente em matéria tributária. Cadernos de Direitu Tributário e Finançus Públicas, n. 21.

FLAKS, Milton. Comentários à Lci de Execução Fiscal. Rio de Janeiro, 1981.

FREITAS, Vladimir Passos de (Coord.). Execução fiscal: doutrina e jurisprudência. São Paulo: Saraiva, 1998.

LIMA, Sebastião de Oliveira. Suspensão da prescrição prevista pelo decreto-lei 1.569, de 8.8.77. Resenha Tributária, ed. 31. $4^{\circ}$ trim.. 1977, p. 356.

MARTINS, Ives Gandra da Silva. A prescrição no direito tributário brasileiro. Resenha Tributária, 1975.

MORAES, Bernardo Ribeiro de. Normas gerais de direito tributário. Revista de Direito Público, n. 31.

PEREIRA, Caio Mário da Silva. Instituições de direito civil. 2. ed. Rio de Janeiro: Forense, 1966.

PIMENTA, Marcos Rogério Lyrio. A prescrição intercorrente no processo administrativo tributário. Revista Dialética de Direito Tributário, n. 71. p. 120.

RODRIGUES, Silvio. Direito Civil. 7. ed. Saraiva: São Paulo. 1977. v. I.

SAKAKIHARA, Zuudi. In: FREITAS, Vladimir Passos de (Coord.). Execução fiscal: doutrina e jurisprudência. São Paulo: Saraiva, 1998.

SOUZA, Hamilton Dias de. Comentário ao Código Tributário Nacional. São Paulo, 1975, v. 1.

SOUZA, Rubens Gomes. Comentários ao Código Tributário Nacional. São Paulo: Revista dos Tribunais, 1975.

SOUZA, Rubens Gomes. Normas gerais de direito financeiro. Revista de Direito Administrativo, v. 37. 
THFODORO JÚNIOR, Humberto. Lei de Execução Fiscal: comentários e jurisprudência. São Paulo: Saraiva, 1995.

TÔRRES, Heleno Taveira. Funções das leis complementares no sistema tributário nacional -. hierarquia de normas - papel do Código Tributário Nacional no ordenamento. Revista de Direito Tributário, n. 84, p. 53.

VELOSO, Carlos Mário da Silva. A decadência e a prescrição do crédito tributário as contribuições previdenciária - a lei 6.830, de 22.9.1980: disposições inovadoras. Revista de Direito Tributúrio, n. 9-10, p. 80-192. 